\title{
3. Women's Work is Never Done: The Pursuit of Equality and the Commonwealth Sex Discrimination Act
}

\author{
Marian Sawer
}

The campaign for the Sex Discrimination Act 1984 (Cth) (SDA) lasted more than a decade-or did it? In fact, the campaign for effective sex discrimination legislation has never ended. The champagne and cake of 1984 marked one victory in a continuing struggle. Continual effort has been required even to keep a specialist sex discrimination commissioner, while repeated budget cuts have depleted the resources needed to be effective. The two-decades-long campaign to enhance the statutory powers of the commissioner has also not yet borne fruit. Meanwhile, industrial relations changes contribute to new inequalities, while decision makers assume that discrimination has already been dealt with. This chapter will reflect on the history of the pursuit of equality by the organised women's movement in Australia and the changing nature of the obstacles in the path.

\section{The Prehistory of the SDA}

It is now 25 years since the $S D A$ came into force. The Act had a long prehistory and this chapter touches on the decades spent by women advocating for gender equality guarantees and then protecting the Act from sometimes unfriendly governments.

The modern history of demands for effective Commonwealth guarantees of gender equality starts in many ways with feminist campaigner Jessie Street. In 1942, when the Commonwealth Government began considering amendments to the Constitution to facilitate postwar reconstruction, Street wrote to Prime Minister John Curtin informing him that women in the Allied democracies were requesting constitutional change to 'extend to women all rights, status and opportunities enjoyed by men with provision that any sex discrimination prescribed in laws or regulations be invalid'. ${ }^{1}$ She asked Curtin for a constitutional

1 Heather Radi, Jessie Street: Documents and Essays, Women's Redress Press, Sydney, 1990, p. 130. See also, Marian Sawer and Jill Vickers, 'Women's Constitutional Activism in Australia and Canada' (2001) 13(1) Canadian Journal of Women and the Law 9. 
equality guarantee and this demand was included in the Australian Women's Charter drawn up in Sydney by a wartime conference of some 90 women's organisations. Despite Street's vigorous advocacy and the wartime mobilisation around the Australian Women's Charter, gender equality did not become part of the 1944 Constitutional Referendum on postwar reconstruction and democratic rights. ${ }^{2}$ As has so often been the case in recent years, Street's advocacy for gender equality was to be more effective at the transnational than the national level. As an Australian delegate to the founding conference of the United Nations, she was one of a handful of feminist delegates that included Berta Lutz from Brazil and Minerva Bernardino from the Dominican Republic. They achieved the inclusion of a commitment to the equal rights of men and women in the Preamble to the Charter and of the word 'sex' in the phrase 'without distinction as to race, sex, language or religion', which appears in four different articles. Street was also effective in lobbying for Article 8 of the Charter on equal employment opportunity for men and women in the new organisation. ${ }^{3}$ Bodil Bengtrup from Denmark successfully moved for the establishment of a UN Commission on the Status of Women (rather than the sub-commission originally decided on) and Street was elected its Vice-President in 1947.

Back in Australia, however, the Cold War brought Street into disrepute and demands for a general prohibition of sex discrimination receded from view, being widely regarded as having something to do with communism. This idea lingered on into the 1970s, resulting in members of the Australian Security and Intelligence Organisation (ASIO) lurking in the shrubbery outside women's liberation meetings. ${ }^{4}$

Meanwhile, women who felt dissatisfied with their lot as Brian's wife and Jenny's mum were famously being recommended to have a cup of tea, a Bex and a good lie down. In many areas of employment, including the Commonwealth Public Service, women continued to be subject to the infamous marriage bar and were fired if they committed the sin of matrimony, losing their superannuation in the process. ${ }^{5}$ The Commonwealth marriage bar lasted until 1966, long after such bars had been removed elsewhere - that is, in all comparable countries except Ireland. Things began to move again in the 1960s, with the increased entry

\footnotetext{
2 It also did not become part of subsequent referendum proposals. Australia remains the only country that has amended its constitution (or introduced a new one) since World War II without incorporating the principle of gender equality.

3 Hilkka Pietilä, The Unfinished Story of Women and the United Nations, United Nations, New York, 2007, p. 11.

4 For ASIO photos of women arriving at a Canberra women's liberation meeting, see National Archives of Australia, Series No. A6122, Accession No. 2004/00686598.

5 Marian Sawer (ed.), The Removal of the Commonwealth Marriage Bar: A Documentary History, Centre for Research in Public Sector Management, University of Canberra, ACT, 1991, <http://pandora.nla.gov.au/ pan/21883/20041011-0000/www.wel.org.au/issues/work/Marriage_Bar.pdf>
} 
of women into higher education and the increased demand for women in the labour market. Attitudes were slow to shift, however, and were patronising in a way that would be totally unacceptable today.

Figure 3.1 Cover story, The Bulletin, 23 September 1967

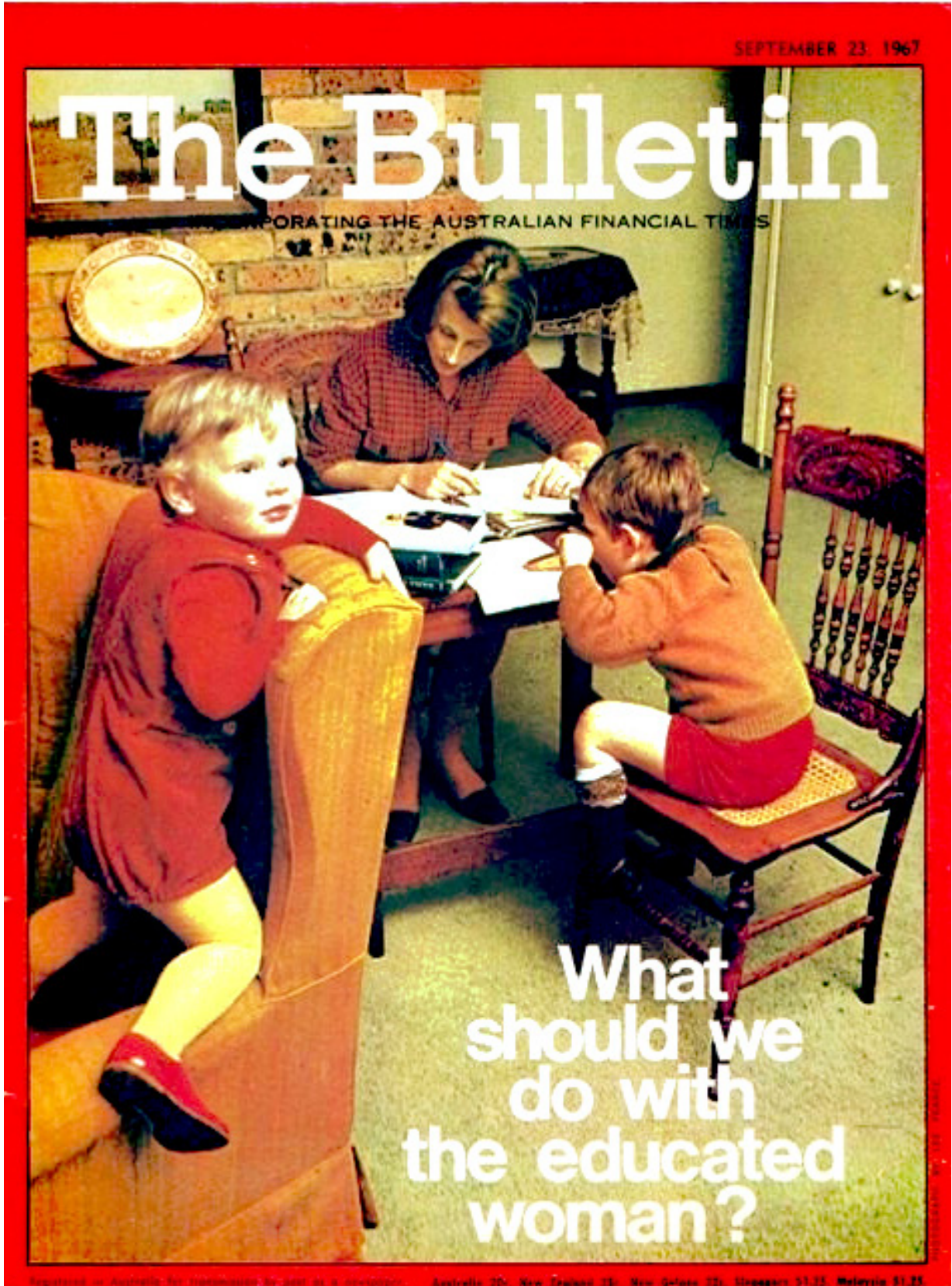

Courtesy APC Magazines 
In 1967, a cover story, 'What shall we do with the educated woman?', appeared in the The Bulletin, the leading Australian current affairs journal of the period. It was about an influx of married women into Macquarie University in 1967, its first year. The women had formed a group to organise a creche and the article quoted the Vice-Chancellor's reaction: 'They don't have full permission yet, of course. They have yet to prove to us they can establish it, staff it, and keep it going. It just isn't possible for university funds to be used for a minority. ${ }^{6}$

This view of married women as a minority and a request for a university childcare centre as novel and strange is a good illustration of the times. So too is the accompanying commentary by the journalist: 'Publicity has been showered on the Mums of Macquarie since the first mention of their childminding centre became known, and much of it has been a little absurd. They cannot, of course, take babies to lectures... They don't shell peas in the common-room or discuss the problems of napkin service.' ${ }^{7}$

Figure 3.2 WEL-Diamond Valley and women's liberation marching in 1973

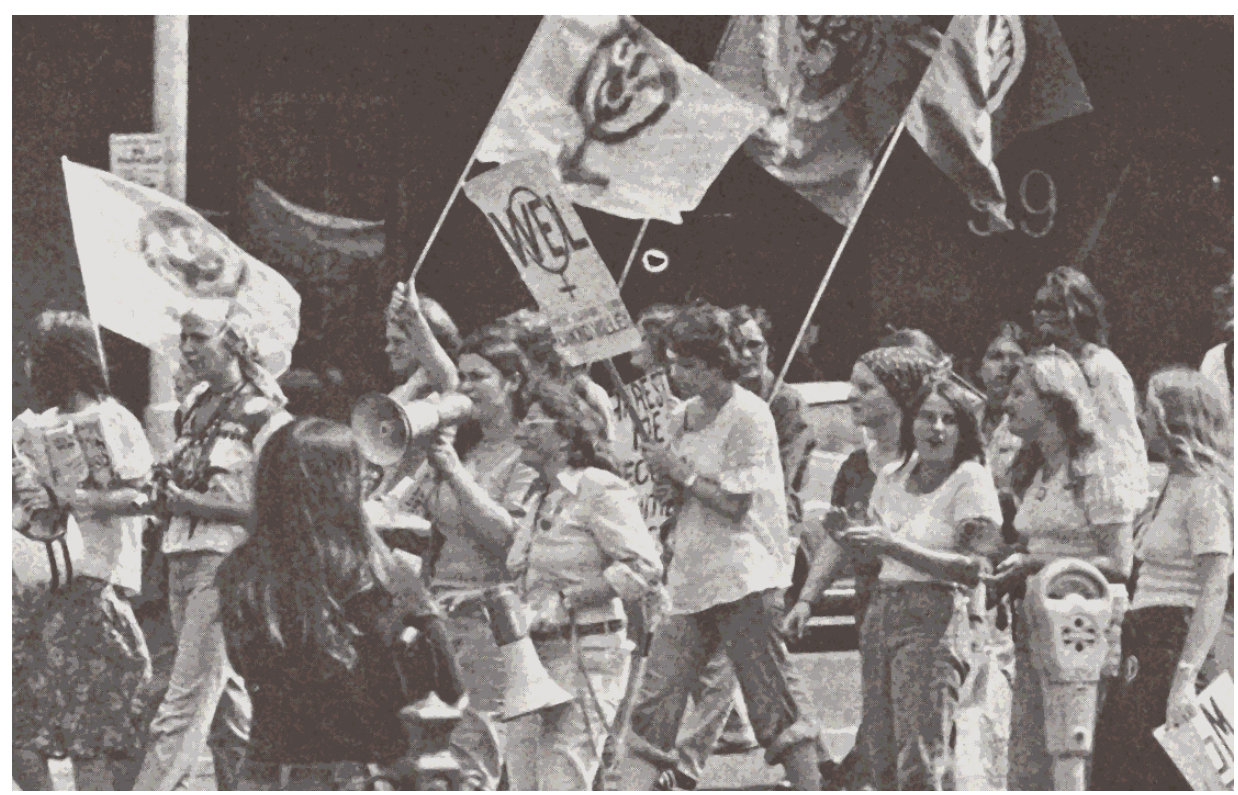

Photo: Sandy Turnbull

This kind of trivialising of married women was indicative of the attitudes for which the new wave of the women's movement was shortly to invent a word: 'sexist'. Society had overlooked and wasted women's skills and talents, marooned them in the suburbs, expected them to spend the most productive

6 April Hersey, 'What shall we do with the educated woman?', The Bulletin, 23 September 1967, p. 23.

7 Ibid. 
part of their lives in housework and then discounted their views as simply those of 'housewives'.$^{8}$ By the beginning of the 1970s, women's pent-up frustration at their treatment was about to explode.

A new wave of the women's movement swelled and in 1972 a new organisation, the Women's Electoral Lobby (WEL), succeeded in making sex discrimination a major campaign issue in the federal election. In response to WEL's agendasetting work, Senator Lionel Murphy, soon to be Attorney-General, announced in November 1972 that ' $[\mathrm{t}]$ he need to remove discrimination against women is obvious and will have early priority from a Labor government' ${ }^{\prime}$

While the Whitlam Government moved quickly to ratify International Labour Organisation (ILO) Convention 111 on Discrimination in Employment and Occupation and to establish national and State employment discrimination committees, legislation took longer to appear. One must remember that this was before the adoption of the UN Convention on Elimination of All Forms of Discrimination Against Women (CEDAW) in 1979, so the constitutional grounds for federal legislation were less clear, quite apart from the enormous agenda of the Whitlam Government in the area of law reform. Nonetheless, in August 1975, the government did circulate a memorandum on a 'Proposed Bill to Prohibit Discrimination Against Persons by Reason of their Sex or Marital Status' ${ }^{10}$ By then, of course, it was too late and the dismissal of the government in November meant that the proposed Sex Discrimination Act did not eventuate.

Lobbying continued at the federal level, while women started gaining sex discrimination legislation at the State level - first in South Australia in 1975 and then in New South Wales and Victoria. The federal minister with responsibility for women's affairs, R. J. Ellicott, was persuaded of the need for sex discrimination legislation, as was the convenor of his National Women's Advisory Council, Beryl Beaurepaire. The National Party ministers in cabinet, however, were fiercely opposed and had support from the newly formed Women Who Want to be Women (WWWW). While Beaurepaire engaged in agenda setting on the need for anti-discrimination legislation, Babette Francis and Jackie Butler of WWWW were vociferous in opposition. Nonetheless, federal sex discrimination legislation was the centrepiece of the draft plan of action for the UN Decade of Women, drawn up after an unprecedented series of town hall meetings with

\footnotetext{
8 See Di Graham, 'Through Life in Pursuit of Equality' in Jocelynne Scutt (ed.), Different Lives, Penguin, Ringwood, Vic., 1987, pp. 179-87.

9 Jocelynne Scutt, 'Legislating for the Right to be Equal' in Cora V. Baldock and Bettina Cass (eds), Women, Social Welfare and the State, Allen \& Unwin, Sydney, 1988 [1983], pp. 230-1.

10 In retrospect, the fact that the only bill to be enacted was the Racial Discrimination Act was perhaps a blessing in disguise; it made an ideal test case before the High Court for the use of the external affairs power as a constitutional base for federal human rights legislation (in Koowarta, 1982). This meant that the constitutionality of the use of the external affairs power to enact human rights legislation was established before the more controversial SDA came along.
} 
women around Australia, culminating in a national meeting in the Academy of Science in Canberra in 1980. Despite being adopted by delegates whose election was overseen by the Australian Electoral Office, the Plan of Action was again blocked by the National Party.

At the mid-decade conference in Copenhagen, Minister Ellicott did manage to sign CEDAW, the new United Nation's Women's Convention. He achieved this despite WWWW trying physically to prevent him. They had acquired press accreditation for the conference from the Ballarat Courier and the Toorak Times. Ellicott and Andrew Peacock, as Minister for Foreign Affairs, issued a joint statement saying that signature of the Convention was an important indication of 'Australia's policy of equality for women and the elimination of discrimination'. ${ }^{11}$ There was, however, no progress towards ratification of the Convention before the election of the Hawke Government.

Meanwhile, classified job advertisements in papers such as the Sydney Morning Herald continued to be divided between those for men and boys and those for women and girls. There was still an assumption that jobs that involved responsibility and had a career structure attached to them were for men, even though an increasing number of women had been able to take advantage of the Whitlam Government's abolition of tertiary fees to go to university. Often they had originally been trained as nurses or secretaries, as these were regarded as suitable jobs for women to have before they were married. Now these former nurses and secretaries were finding they had the brains to be brain surgeons or chief executive officers, and not only handmaidens as originally planned.

\section{The SDA and its aftermath}

Meanwhile, in Federal Parliament, the Labor Opposition was increasing the pressure on the issue and in 1981 Shadow Minister Senator Susan Ryan introduced her Sex Discrimination Bill as a Private Senator's Bill. This was a broad-ranging bill, drafted by early WEL member and barrister Chris Ronalds. Sex discrimination legislation became a major plank of the Labor Party's election policy, endorsed by representatives of some 26 national women's organisations, most of which had participated in Beaurepaire's UN Decade of Women consultation process. The momentum now seemed unstoppable and, with the election of the new Labor government in 1983, the way seemed clear for action at last. A Sex Discrimination Bill was introduced into Parliament in June 1983

11 Australian Foreign Affairs Record, July 1980, p. 240. 
and CEDAW was ratified in July. By now the High Court had confirmed in the Koowarta case that the federal government was able to use its external affairs power to meet obligations under international human rights conventions.

It was at this point that a public furore erupted, as described by other contributors to the anniversary conference. While Elaine Nile, of the Festival of Light, made arrangements for busloads of opponents to come to Canberra to demonstrate against 'the Sex Bill' outside Parliament, supporters of the Bill were also busy. Pamela Denoon, the national coordinator of WEL, stitched together a coalition of women's organisations from across the political spectrum to support the Bill, ranging from the National Council of Women through to the Union of Australian Women. When the Bill finally passed through both houses ${ }^{12}$ - after 53 amendments to placate seemingly implacable opponents - Denoon organised a large celebration party on the lawn in front of Parliament House to thank Susan Ryan and all the parliamentary supporters of the Bill, including Liberals such as Ian Macphee and Kathy Martin and Democrat Janine Haines, as well as tireless Labor advocates such as Senator Pat Giles. To go with the champagne there was a large purple, green and white cake in the shape of the women's symbol.

Once the legislation was through, what did it mean for women? For some it was empowering just to know there was now a law to prevent women being treated less favourably by employers because they were women, or because they were married women. Increasingly, women believed that they had the right to the same range of employment opportunities as men, the right not to be sexually harassed at work and the right to be paid equally - although the substantive achievement of the last two rights proved more elusive. In this new era, women became increasingly visible in public life - for example, in February 1986, Lynne Simons, the first woman Sergeant-At-Arms in the House of Representatives, led in the first woman Speaker, Joan Child. Women had come a long way in a Parliament, which until 1969, would not even employ a woman for the job of Hansard reporter, despite a lack of men with the shorthand skills required.

Despite such progress, Australia has been slipping down the Inter-Parliamentary Union's league table for representation of women in national parliaments for at least the past decade; today it ranks in thirty-third place along with Afghanistan. ${ }^{13}$ This is because other countries, particularly since the United Nations' Fourth World Conference on Women (the Beijing Conference), have been taking more

12 While the passage of the bill was gruelling, the debate was far from being the longest in the Senate's history, as is sometimes claimed. The records of the Senate Table Office show that it was only the eleventh-longest debate in the period 1950-86. For example, while there were 17 hours of debate on the Sex Discrimination Bill, there were almost 70 hours on the Communist Party Dissolution Bill (Marian Sawer, Making Women Count: A History of the Women's Electoral Lobby, UNSW Press, Sydney, 2008, p. 184).

13 Inter-Parliamentary Union, Women in National Parliaments, 31 July 2009, <http://www.ipu.org/wmn-e/ classif.htm> 
vigorous action to ensure the presence of women in their parliaments, and more than 100 countries have adopted some form of electoral quota for women. The presence of women in elected office at local government level was even lower (28 per cent) than at the parliamentary level across Australia (31.6 per cent). ${ }^{14}$ Nonetheless, it is now widely accepted in Australia, as elsewhere, that maledominated political representation implies a democratic deficit, making it clear that there is 'something wrong with the picture' in cases such as the all-male 1992 Tasmanian Cabinet.

\section{Figure 3.3 Tasmanian Cabinet. The Mercury, 19 February 1992, p. 2}

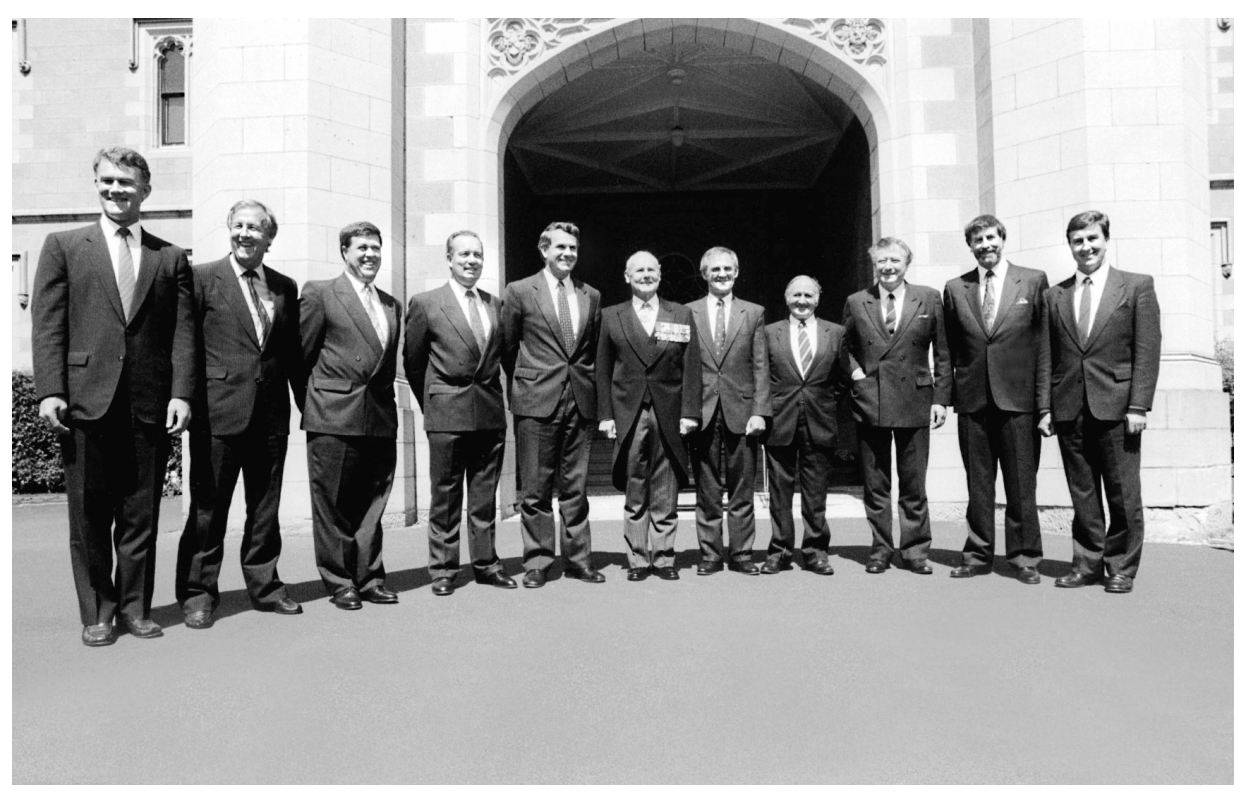

Courtesy The Mercury

The survival of the $S D A$ itself could also never be taken for granted. Already in 1986 there had to be an eleventh-hour effort to ensure there was a body to continue implementing the Act. The Human Rights Commission had been created in 1981 with a 'sunset' clause that came into effect after five years and the Attorney-General had delayed any action to replace it, because he was (unsuccessfully) trying to put through a Bill of Rights in the same package. On top of this, the Expenditure Review Committee of cabinet had decided in 1986 to abolish the commission, having temporarily overlooked the fact that it was responsible inter alia for implementing the government's new Act. Then Sex Discrimination Commissioner, Pam O'Neil, had to undertake a major campaign to ensure legislation was passed in time for a new body (the Human Rights and

14 Local government figures from October 2009, parliamentary figures from 9 April 2010 - both from the Parliamentary Library, Parliament of Australia, Canberra. 
Equal Opportunity Commission) to take over the functions of the old commission on its expiration at the end of $1986 .{ }^{15}$ The commission was never really secure, however, being threatened with abolition by the Coalition's Future Directions manifesto released under the auspices of John Howard in 1988.

The SDA intermeshed with a range of sometimes challenging policies to address broad forms of discrimination against women. One of these was the failure of workplaces to acknowledge that employees had family responsibilities and that work practices needed to be more flexible to accommodate these responsibilities. Both men and women workers had such responsibilities and in 1983 the Hawke Government was elected with a commitment to ratify ILO Convention 156, which recognised that this was so. The Office of the Status of Women designed a 'Joe Average' poster to promote the Convention and to normalise the practice of male workers taking their share of family responsibilities.

Convention 156 was controversial because it required family-friendly work practices and conditions that would enable men to take a more equal role in raising their children. Although the Convention had been part of the Hawke Government's election policy, there were many delays in ratifying it, on the ground of States' objections. It again became part of Labor election policy in 1990 after determined advocacy by Labor feminists. At last, the Convention was ratified and the Office of the Status of Women led its implementation with a 'Sharing the Load' community education campaign that was highly commended by the United Nations. A Work and Family Unit was established in the industrial relations portfolio to continue policy development on ways to enable both parents to combine family responsibilities with paid work. The unit was abolished under the Howard Government in 2003, but the Rudd Government re-established an Office for Work and Family in the Department of the Prime Minister, with responsibility for paid parental leave and other 'work/life' issues.

The need to amend the SDA to prohibit both direct and indirect discrimination on the ground of family responsibilities has long been recognised-inside and outside government - and was once again recommended by the Senate Standing Committee on Legal and Constitutional Affairs, in 2008. At the time of the silver anniversary of the Act, the family responsibilities provision was still limited to termination of employment but, as we shall see below, this was one of the few recommendations of the committee endorsed in the Rudd Government's belated response in May 2010.

In one interesting development, soon after Australia's ratification of CEDAW in 1983, Justice Elizabeth Evatt took her place on the UN committee responsible for its oversight. Almost immediately, she began to play an important role in the development of CEDAW processes and jurisprudence.

15 Marian Sawer, Sisters in Suits: Women and Public Policy, Allen \& Unwin, Sydney, 1990, pp. 212-13. 
Figure 3.4 Justice Elizabeth Evatt

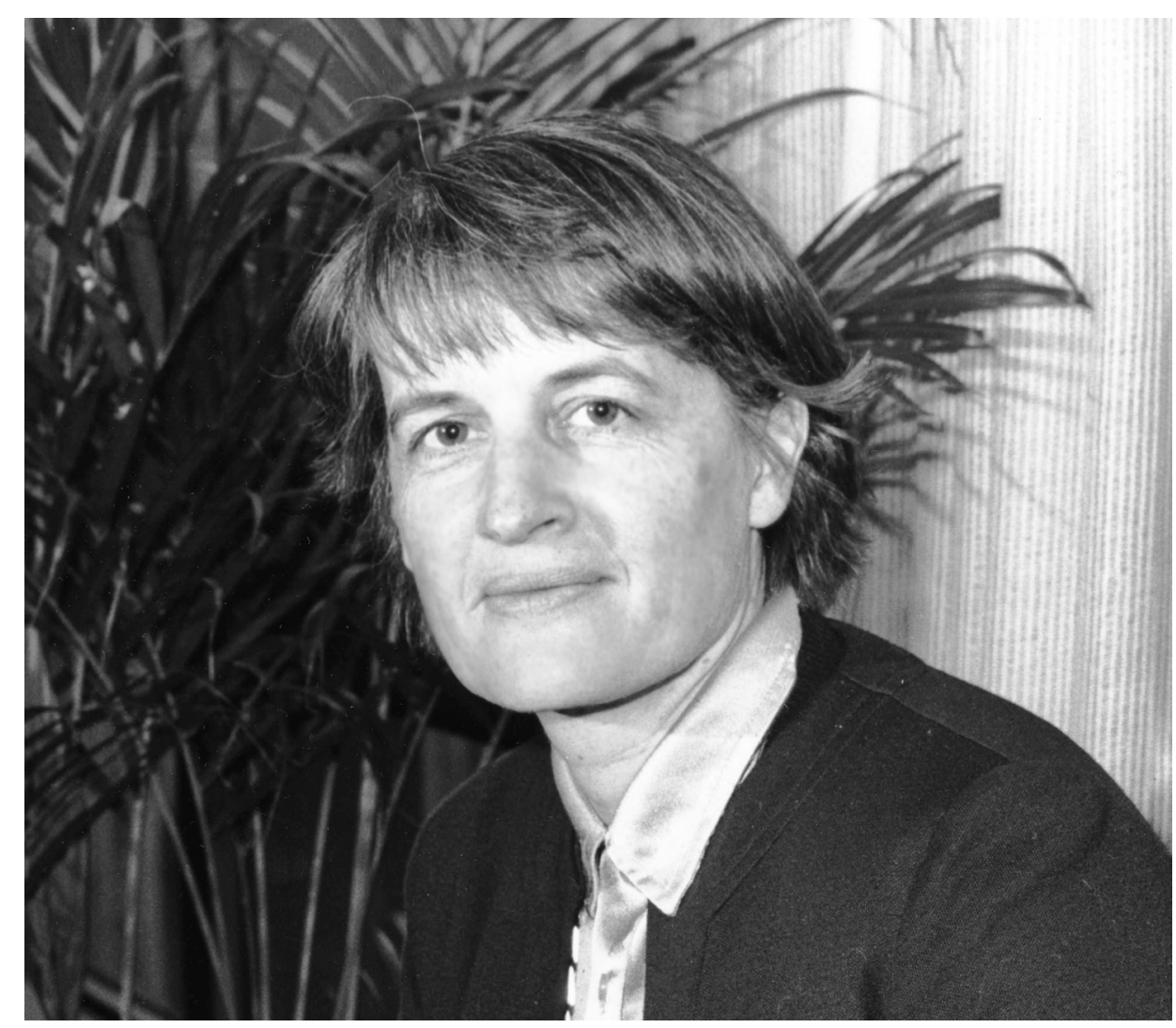

Courtesy Elizabeth Evatt

One of her most significant contributions was the drafting of the General Recommendation No. 19 (1992) on violence against women. The Convention text does not directly address the issue, so the General Recommendation is particularly important in clarifying that gender-based violence constitutes discrimination as defined under the Convention and that attitudes by which women are regarded as subordinate contribute to such violence. The General Recommendation also made it clear that because the concept of discrimination is not restricted to acts by or on behalf of government, states may be held responsible for private acts of violence if they fail to act with due diligence to prevent, investigate and punish such acts. In the case of AT v Hungary (2/03), the CEDAW Committee found that the state party was in breach of the Convention because it had failed to ensure the protection of 'AT' from her former common-law husband and had failed to enact specific domestic violence legislation to provide for protection orders and support services such as shelters. ${ }^{16}$

16 For discussion of this case, see: Bal Sokhi-Bulley, 'The Optional Protocol to CEDAW: First Steps' (2006) 


\section{Reforming the SDA}

Back at home, the women's movement was still working from both inside and outside government to improve the effectiveness of the $S D A$. These efforts bore fruit with successive amendments passed in 1992 and 1995. The amendments flowed from a House of Representatives inquiry of 1989-92. At first, the inquiry, put together quickly to take advantage of the fifth anniversary of the passage of the Act, looked unpromising - with an all-male committee and ambiguous terms of reference. The somewhat disturbing terms of reference included the formulation of 'the extent to which the objects of the SDA have been achieved or are capable of being achieved by legislative or other means' ${ }^{17}$ With the help of inquiry secretary Jon Stanhope, later Chief Minister of the Australian Capital Territory, feminists were, however, able to ensure a highly participatory inquiry process, including public seminars jointly sponsored by women's units.

The first public seminar was held in November 1990 and was co-hosted by the ACT Division of the Royal Australian Institute of Public Administration (of which Marian Sawer was then Vice-President). It was led off by discrimination expert Professor Margaret Thornton and included a dazzling cast of feminist legal and policy activists, from Justice Elizabeth Evatt to Jocelynne Scutt, Moira Rayner and Philippa Hall (for award issues) as well as John Basten, whose work on improving the definition of indirect discrimination was to be invaluable. Helen Styles of the Department of Foreign Affairs and Trade, a complainant in a major test case on the Act's indirect discrimination provisions, was asked by an industry representative whether voluntary EEO programs would not be less stressful than legal battles. She replied that if voluntary compliance worked, Moses would have handed down 'The Ten Guidelines'.

The report of the inquiry, Half Way to Equal, reflected much of what was learnt through such seminars and was promoted very effectively in the media by energetic committee chair, Michael Lavarch, later to be Attorney-General. ${ }^{18}$ Not long before the tabling of the report in April 1992, a new coalition of national women's organisations called CAPOW! had been established, which proceeded to make the strengthening of the Act the subject of its first conference. Another element in this favourable configuration was the appointment of Anne Summers to the Prime Minister's Office. Prime Minister Paul Keating had been having 'women trouble', with the Opposition press boxing his maiden speech on the eve of International Women's Day 1992. As a new Member of Parliament in 1970, he had attacked the Gorton Government over the increased number of

17 House of Representatives Standing Committee on Legal and Constitutional Affairs, Inquiry into Equal Opportunity and Equal Status for Australian Women, 1989, Terms of Reference.

18 Lavarch had taken over as chairman of the Legal and Constitutional Affairs Committee after the 1990 election, when the inquiry was reinstated. 
women in the workforce and asked what it was doing to 'put the working wife back in her home'. A bad press on women's issues, combined with his abysmal rating with women voters, led to the appointment of Summers to recapture the 'women's vote'.

The combination of insider and outsider advocacy brought success when the Prime Minister announced the first set of amendments to the Act at the CAPOW! conference in September and foreshadowed the second set, which was to come in 2005. The immediate changes included strengthening the sexual harassment provisions, making dismissal on the ground of family responsibilities unlawful and removing the exemption for industrial awards. The changes that had to wait until 2005 included strengthening the special measures provision and, most importantly, reversing the onus of proof in cases of indirect discrimination, so that an employer had to demonstrate the business necessity for requirements that disadvantaged women.

At the same conference, the Prime Minister announced the government's acceptance of the longstanding women's movement's demand for contract compliance to be introduced as an additional incentive for employers to comply with the Affirmative Action Act. This meant that from 1992, companies named in Parliament for non-compliance with the Act would be ineligible for government contracts or industry subsidies. Contract compliance is still part of the federal government procurement policy overseen by the Department of Finance, but has little effect on those named for non-compliance, which tend to be companies that do not have business with the government. The Coalition objected to the introduction of contract compliance and also to the removal of the exemption in the SDA for industrial awards. The Shadow Minister, Senator Jocelyn Newman, decried the new commitments with a press release headed 'Keating's sex speech a bit limp' ${ }^{19}$

In a classic but unusual example of policy transfer, some of the improvements to the Commonwealth Act had already been trialled in the new ACT Discrimination Act of 1991. The developments in the Australian Capital Territory owed much to feminist advocates already involved in the federal inquiry, so the policy transfer was not really from a small jurisdiction to a national one, as much of the policy learning had already taken place.

Under the Howard Government elected in 1996, the women's movement was involved more in defensive actions than moving the agenda forward. It seemed clear that the new government was disinclined to have a Sex Discrimination Commissioner at all. Sue Walpole, then Sex Discrimination Commissioner, was described by the Prime Minister as a 'Labor stooge' and resigned early. She

19 Senator Jocelyn Newman, Press release, 19 September 1992. 
was not replaced for 14 months. A cartoon by Cathy Wilcox depicted feminist frustration at this long wait and the uncertainty over the position being filled. It shows the Prime Minister delivering an answering-machine message.

Figure 3.5 Wilcox cartoon, The Age, 19 September 1997

Beeep! The office of the Commissioner for Sex Discrimination is currently unattended. If you're a woman and you have a complaint, well, That's just typical. Complain, complain, complain, it's all you women do. Not content to have a nice job and a few sisters in parliament. you want equal pay, childcare and protection as well! Next, you'll be wanting bloody land rights! Face it: Sex discrimination happens. In fact, it's something of a tradition in this country, and well, I'm an unashamed traditionalist. So on with the powder, there's a good love, freshen up your lippy, give up and Go Home.

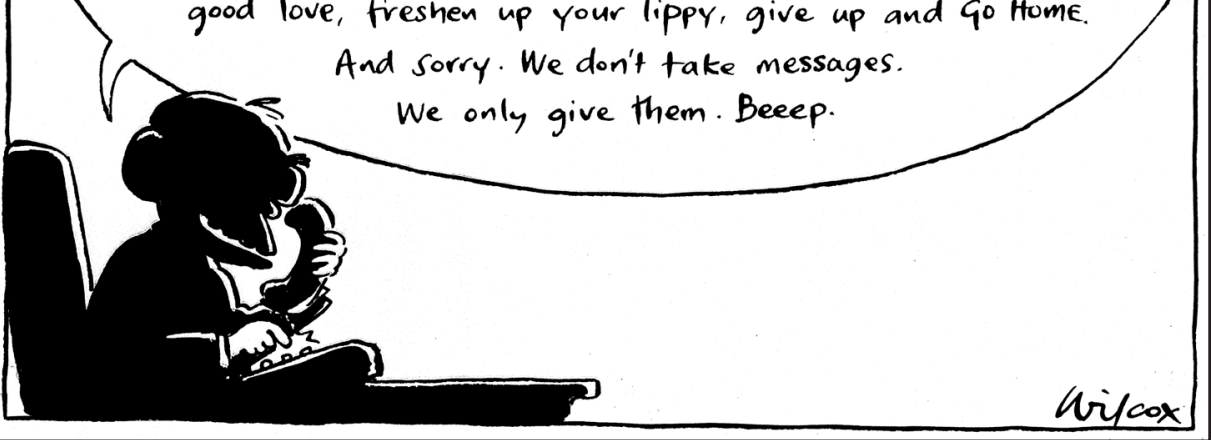

Courtesy Cathy Wilcox

The position was finally filled soon after this very effective cartoon appeared.

Another high-profile campaign was to prevent the watering down of the marital status provisions of the $S D A$. The Federal Court had ruled that a Victorian law restricting access of single women to IVF treatment was inconsistent with the Commonwealth SDA and hence invalid. The Commonwealth Attorney-General, however, granted a fiat to enable the Australian Conference of Catholic Bishops to appeal to the High Court. ${ }^{20}$ The challenge threatened not only single women's access to IVF, but also the marital status provisions of the SDA more generally and WEL-Victoria intervened along with the Human Rights and Equal Opportunity Commission. It was the first time a women's group had been granted status in the High Court. The bishops, who had not been a party to the original case, were unsuccessful.

20 Ex parte Australian Catholic Bishops Conference (2002) 209 CLR 372. 
In the meantime, the government introduced a bill to amend the SDA to allow States and Territories to discriminate on the basis of marital status in the provision of 'assisted reproductive technology services'. Fortunately, the Senate Legal and Constitutional Affairs Committee was chaired by Senator Marise Payne, who helped hold the line against the various attempts by the Howard Government to weaken the Act. The committee found that the Bill was unable to achieve its objective of providing a child with the care and affection of a mother and father. ${ }^{21}$

The Howard Government also made unsuccessful attempts before and after the 2004 federal election to amend the $S D A$ to provide an exemption for male-only teachers' scholarships - an initiative opposed by women's groups and by the then Sex Discrimination Commissioner, Pru Goward.

In addition, there were continuing struggles over the resourcing and structure of the Human Rights and Equal Opportunity Commission, which had responsibility for administering the Act. Resourcing of the commission and of the Sex Discrimination Commissioner became one of the recurrent themes of women's conferences. These struggles had begun under the Hawke Government but were exacerbated under the Howard Government, which straightaway made a 40 per cent cut to the commission's budget, meaning a loss of one-third of its staff in 1997-98. It went further by introducing successive bills to remove the specialist commissioners, including the Sex Discrimination Commissioner, and to require the commission to obtain permission from the Attorney-General before intervening in court proceedings. Fortunately, these bills were blocked in the Senate. WEL, along with feminist lawyers, wrote submissions and appeared before the Senate Legal and Constitutional Affairs Committee to argue the deleterious effects of losing specialist expertise.

WEL has continued to advocate the importance of the specialist commissioners and the overloading caused by the doubling up of responsibilities under the Howard Government. Rather than filling the vacant commissioner positions, however, the Rudd Government in 2008 formalised the doubling up of responsibilities, so that each commissioner carries two portfolios: the Sex Discrimination Commissioner is also the commissioner responsible for Age Discrimination. The Human Rights Commission also suffered disproportionately in the 2008 Budget, with the efficiency dividend resulting in a 14.5 per cent funding cut across the commission, including the sex discrimination area.

It should be noted here that with the abolition or muting of women's policy units in government, the role of a relatively independent Human Rights Commission in policy advocacy becomes increasingly important. This was particularly

21 Louise Chappell, 'Winding back Australian Women's Rights: Conventions, Contradictions and Conflicts' (2002) 37(3) Australian Journal of Political Science 475. 
notable with Commissioner Goward's campaign for paid maternity leave and more recently with the campaigns of Commissioner Liz Broderick-both on paid maternity leave and on a range of gender equality issues.

\section{Conclusion}

So where are we now? The Rudd Government was elected in 2007 without a women's policy - the first time that the Australian Labor Party (ALP) had gone to an election without a women's policy since 1977. Like the Blair Government in the United Kingdom, it had been convinced that any trace of feminism would be an electoral turn-off for the blue-collar workers being wooed back to the party. Despite the absence of an overall plan on how to address gender inequalities, the ALP did have policies that included the strengthening of the Commonwealth $S D A$, the ratification of the Optional Protocol of CEDAW and strengthening the Office for Women (but without moving it back to the Department of Prime Minister and Cabinet or ensuring that the portfolio minister was in cabinet).

The loss of capacity within government to monitor policy for its impact on women and the loss of political will to act on such gender auditing had contributed to a range of adverse outcomes, particularly with WorkChoices and its impact on the pay and conditions of low-paid women workers. The Rudd Government legislated to undo the more extreme aspects of WorkChoices but without directly addressing the gender pay gap. The House of Representatives inquiry into pay equity reported in late 2009-well after the setting up of the new industrial relations system under Fair Work Australia. Meanwhile, the gender pay gap in the ordinary-time earnings of full-time workers increased to 17.2 per cent in Australia as a whole, and to 25.9 per cent in Western Australia. ${ }^{22}$

The Rudd Government legislated in 2010 for 18 weeks' paid maternity leave to take effect from 2011, ${ }^{23}$ before which Australia remained one of only two Organisation for Economic Cooperation and Development (OECD) countries without such a basic entitlement at the national level. Childcare policy had also been in retreat since the 1990s. In late 2008, the collapse of ABC Learning, which had become the largest childcare corporation in the world, illustrated the dangers of using public money to subsidise the growth of a for-profit corporate childcare market. No resolute action was on the agenda-despite the findings

22 Australian Bureau of Statistics, Average Weekly Earnings, May 2009, ABS Cat 6302.

23 Paid Parental Leave Act 2010 (Cth). 
of the Australian Survey of Social Attitudes that for-profit child care was the least-preferred and government provision the most-preferred form of child care in Australia. ${ }^{24}$

Twenty-five years after the SDA came into force, our expectations have risen considerably. The Senate Legal and Constitutional Affairs Committee produced an excellent report in December 2008 on what needed to be done in the short term to strengthen the $S D A$ and make it effective again. As we have noted, the Rudd Government was elected with a platform commitment to 'strengthen and improve the SDA and the powers of the Commissioner'. Despite this commitment, and another to respond to parliamentary committee reports within three months, a response to the senate committee report on the SDA did not appear until May 2010. And when it came, there were still no new powers for the Sex Discrimination Commissioner to take a more proactive role, as was the case with comparable commissions in Canada, New Zealand and the United Kingdom and as recommended by the senate committee. Women's organisations had been campaigning since the 1980s for such powers, to lift the burden of achieving change from the victims of discrimination. There was also no role for the Sex Discrimination Commissioner to monitor and report on progress towards gender equality - also recommended by the senate committee-let alone the resources to do so. All such matters were put off for the foreseeable future as part of the 'consolidation project'. The argument that a present reform would block the way for more sweeping measures in the future comes straight out of Cornford's classic compendium of tactics for resisting reform. ${ }^{25}$

By the time of the silver anniversary of the Sex Discrimination Act, many of those who had helped bring it into existence were themselves silver-haired. Nonetheless, it was clear that their work was far from over. The Act had required constant vigilance from the time of its difficult birth. And while the 2007 ALP National Platform had contained a specific commitment to 'strengthen and improve the Sex Discrimination Act and the powers of the Commissioner to protect women against discrimination on the basis of gender and family responsibilities', the 2009 National Platform had only a non-specific commitment to 'eliminate all forms of discrimination, vilification or harassment and to harmonise antidiscrimination laws and procedures'. As in the previous 25 years, now there was an easy assumption by government that sex discrimination was something that had already been dealt with. The achievement of strong accountability

\footnotetext{
24 Australian Survey of Social Attitudes 2009 (<http://aussa.anu.edu.au $>$ ). Of the respondents to this regular national survey, 35 per cent preferred government provision compared with 18 per cent preferring business provision, with other forms of provision (community organisations or family) coming in between. 25 F. M. Cornford, Microcosmographia Academica: Being a Guide for the Young Academic Politician, Bowes \& Bowes, Cambridge, UK, 1908, p. 17.
} 
frameworks and legislative instruments to ensure further progress was low on the agenda, and only continued campaigning by equality seekers was likely to change this. Indeed, women's work is never done.

\section{Bibliography}

\section{Books and articles}

Chappell, Louise, 'Winding back Australian Women's Rights: Conventions, Contradictions and Conflicts' (2002) 37(3) Australian Journal of Political Science 475.

Cornford, F. M., Microcosmographia Academica: Being a Guide for the Young Academic Politician, Bowes \& Bowes, Cambridge, UK, 1908.

Graham, Di, 'Through Life in Pursuit of Equality' in Jocelynne Scutt (ed.), Different Lives, Penguin, Ringwood, Vic., 1987.

Hersey, April, 'What shall we do with the educated woman?', The Bulletin, 23 September 1967, p. 23.

Pietilä, Hilkka, The Unfinished Story of Women and the United Nations, United Nations, New York, 2007.

Radi, Heather, Jessie Street: Documents and Essays, Women's Redress Press, Sydney, 1990.

Sawer, Marian, Sisters in Suits: Women and Public Policy, Allen \& Unwin, Sydney, 1990.

Sawer, Marian, Making Women Count: A History of the Women's Electoral Lobby, UNSW Press, Sydney, 2008.

Sawer, Marian (ed.), The Removal of the Commonwealth Marriage Bar: A Documentary History, Centre for Research in Public Sector Management, University of Canberra, ACT, 1997, <http://pandora.nla.gov.au/ pan/21883/20041011-0000/www.wel.org.au/issues/work/Marriage_Bar. $\operatorname{pdf}>$

Sawer, Marian and Vickers, Jill, 'Women's Constitutional Activism in Australia and Canada' (2001) 13(1) Canadian Journal of Women and the Law 9. 
Scutt, Jocelynne, 'Legislating for the Right to be Equal' in Cora V. Baldock and Bettina Cass (eds), Women, Social Welfare and the State, Allen \& Unwin, Sydney, 1988 [1983].

Sokhi-Bulley, Bal, 'The Optional Protocol to CEDAW: First Steps' (2006) 6(1) Human Rights Law Review 143.

\section{Legislation}

Paid Parental Leave Act 2010 (Cth)

Racial Discrimination Act 1975 (Cth)

Sex Discrimination Act 1984 (Cth)

\section{Cases}

Ex parte Australian Catholic Bishops Conference (2002) 209 CLR 372

Koowarta v Bjelke-Petersen (1982) 153 CLR 168

\section{Reports and miscellaneous primary sources}

Australian Bureau of Statistics, Average Weekly Earnings, May 2009, ABS Cat. 6302, Australian Bureau of Statistics, Canberra.

Australian Foreign Affairs Record, July 1980, p. 240.

Australian Survey of Social Attitudes, The Australian National University, Canberra, $2009<$ http://aussa.anu.edu.au $>$

House of Representatives Standing Committee on Legal and Constitutional Affairs, Inquiry into Equal Opportunity and Equal Status for Australian Women, Parliament of Australia, Canberra, 1989..

Inter-Parliamentary Union, Women in National Parliaments, 31 July 2009, $<$ http://www.ipu.org/wmn-e/classif.htm>

Newman, Senator Jocelyn, Press release, 19 September 1992, Parliament House, Canberra. 